\title{
The Problematic of Small-Scale Land Acquisition (Less than 5 Hectares) for Public Interest Development
}

\author{
Donna Okhtalia Setiabudhi \\ Faculty of Law, University of Sam Ratulangi \\ Jl. Kampus Unsrat Bahu, Manado, North Sulawesi, Indonesia. \\ Tel./Fax: +62-431-863886E-mail:_donna_setiabudhi@yahoo.com \\ Submitted: Dec 10, 2015; Reviewed: Jan 22, 2016; Accepted: Feb 13, 2016
}

\begin{abstract}
Land acquisition for public interest development is stipulated in Act No. 2 of 2012 concerning Land Acquisition for Development of Public Interest. One arrangement of land acquisition in legal substances that have been formed are smallscale land acquisition (less than 5 hectares), but it is still governed by very vague and thus susceptible to the multi-interpretation and raises doubts in its implementation. This paper discusses the problematic that arise due to unclear regulations concerning small-scale land acquisition and to provide solutions to these problems. Based on the discussion the authors concluded first, the problematic of small-scale land acquisition is the arrangement of land acquisition that is so vague that there is no clarity regarding the procedures for determining of location, the phase of land acquisition, which excludes public consultation, there is no regulation regarding preventive measures against the impact for the community around location of land acquisition. Second, the solution could be found to this problem is a regulation of small-scale land acquisition should ideally be regulated more comprehensively considering that small-scale land acquisition allows the emergence of adverse effects for the community around location of land acquisition so that the stages of planning and preparation that is set for the large-scale land acquisition is similarly applied for small-scale.
\end{abstract}

Keywords: Agrarian; Land Acquisition; Public Interest

DOI: http://dx.doi.org/10.20956/halrev.v1n1.214

\section{INTRODUCTION}

The arrangement of land rights by state officials through Act No. 5 of 1960 on the Basic Regulation of Agrarian (hereinafter referred UUPA) on the principle of social function of land. The principle of social function of land under Article 6 UUPA determines that "all land rights have social function". In general explanation Number II(4) and explanation article by article elaborated that, "not only property rights but all land rights have social function". This implies that the land rights existing in a person, not solely used for personal interests, but also must provide benefits to the public interest. 
This suggests that UUPA put the public and private interests in a balanced manner in order to achieve the states' goal of prosperity, justice and happiness for all the people of Indonesia and the entire homeland of Indonesia. This means also that social function attached to the land right put ownership or land control has a function for the subject of their rights and has a function for society. The consequence is the use of land must pay attention to 2 (two) interests, the interests of rights holders and the interests of society. Both of these interests must be balanced in this case should not damage each other. The interests of rights holders should not be detrimental to the interests of society and vice versa the public interest should not be detrimental to the interests of the rights holder.

To implement the development for public interest, the government as a party that requires the land to be earmarked for the development of public facilities and then introducing a mechanism called land acquisition in which they are affected by land acquisition are compensated both physical and/or nonphysical given to rights to land, buildings, plants and other objects related to the land. In this case, the ideal compensation is compensation that takes into account the value of justice in society. The existence of compensation as an effort to provide a balance between individual and community rights, but in reality it is not enough to build trust between the communities affected by the development of public interest and the government to obtain land.

Another urgent aspect to be discussed pertaining to land acquisition is an agency procedures and mechanisms for land acqui- sition. At least for land acquisition for the public interest, the government needs to pay attention to a few things: advance notice to the community that will be affected by the development of the public interest, identify the holders of land rights, providing opportunities for participation by the public in the process of land acquisition and provide dispute resolution institutions concerns land acquisition. Then, it is accommodated in legislation governing land acquisition for the development of public interest.

Efforts to improve regulation regarding land acquisition is one of the political will of state officials to put the individual and public interests as the two sides are in line and, not the opposite, conflicting, opposite and facing. The existence of Act No. 2 of 2012 then followed up with the establishment of the Presidential Regulation No. 71 of 2012, No. 40 of 2014, No. 99 of 2014 and No. 30 of 2015, the Regulation of National Land Agency No. 5 of 2012 concerns Technical Guidance on Land Acquisition, as well as the Regulation of Agrarian and Spatial Planning Minister/Head of National Land Agency No. 6 of 2015 concerns the Amendment of the Technical Guidelines of Land Acquisition and the Amendments of the Regulation of the National Land Agency No. 5 of 2012 concerns Technical Guidelines for the Implementation of Land Acquisition.

One legal substances regulated in some legislations for land acquisition are smallscale land acquisition. At first in Presidential Regulation No. 71 of 2012 determines smallscale land area is 1 hectare but in Presidential Regulation No. 40 of 2014 stipulated that the small-scale land area is less than 5 hectares. 
The mechanism of land acquisition for small scale is regulated in the Regulation of Agrarian and Spatial Planning Minister/Head of National Land Agency No. 6 of 2015 does not use the committees of land acquisition but through direct transition such buying and selling, exchange and other agreed way but the determination of land price is remain using appraisal team.

Basically, small-scale land acquisition with an area of 5 hectares is not a simple problem because the area of 5 hectares it is possible that the land is the property of a group of people or land area over a designated location consists of several landowners so that the land acquisition is done can impact on landowners and communities around the land acquisition. Another problem that can arise is the use of land 5 hectares it is possible for the construction of a building or the implementation of activities that impact the physical and social environment around the community. The arrangement of land acquisition is so vague raises doubts on the local government officers. It is can be seen in reality in the city of Manado where a fund of 33 billion rupiah for small-scale land acquisition has not been absorbed until October for local government officials hesitate to carry out the land acquisition.

Opportunity problem and reality shows a tendency hesitations of local governments to implement small-scale land acquisition so authors interested to examine this issue as to how the problems of small-scale land acquisition (less than 5 hectares) and how solutions for small-scale land acquisition in order to realize the certainty law, justice and benefits to society.

\section{METHOD}

This study using a normative-juridical research, an effort to find a legal (in concreto) that is suitable to be applied in resolving certain legal issues. To determine the answer to the questions contained in the formulation of research problems, use statute approach by not forgetting the disclosure of logic ratio and ontology basic the birth of legislation, especially legislation relating to land acquisition and conceptual approach to depart from the views and doctrines developed in legal science.

As the main focus of research is normative-juridical, then the data to be collected is secondary data from positive law, which includes legal materials both primary and secondary and also tertiary. Primary legal materials in the form of legislation, principles and research results related to this research and secondary legal material in the form of documents and literature/readings that includes the basics of theoretical or doctrine that is relevant and tertiary legal material is obtained from the internet, seminars, symposia and workshops associated with land acquisition for development purposes in the public interest and dictionaries that help to translate the legal terms used in the discussion.

\section{ANALYSIS AND DISCUSSION}

The Concept of Land Acquisition for Public Interest

Definition of land acquisition in Act No. 2 of 2012 then elaborated in Presidential Regulation No. 71 of 2012 concerns the Implementation of Land Acquisition for Public Interest and the Regulation of National Land Agency 
No. 5 of 2012 concerns Technical Guidance on Land Acquisition which essentially states that the land acquisition is an activity of land rights release of subject or landowner by providing compensation to them in which the land is held by the government for public purposes. Harsono ${ }^{1}$ suggested that land acquisition is a legal act in the form of releasing the legal relationship that originally existed between the rights holder and their land is necessary, by giving compensation in the form of money, facilities or other, through deliberation to reach an agreement between the landowner with those who need it.

Land acquisition in Bernhard Limbongs' view related to the activity to obtain land by giving compensation to who release or transfer their land, buildings, plants and objects relating to the land. Land acquisition in Bernhard Limbongs' view includes two side dimensions that must be placed in balance between the interests of society and government. $^{2}$

The descriptions above indicate that land acquisition is an activity that includes actions to release the right, the release by the party who are rights holders and or land tenure, earmarked for development activities for the public interest, the release of which is accompanied by compensation so that according to the author the element of acquisition is the release of land rights, rights holders, land tenure, development activities, public interest and compensation.

\footnotetext{
Boedi Harsono. (1991). Hukum Agraria Indonesia Himpunan Peraturan-Peraturan Hukum Tanah. $10^{\text {th }}$ editions. Jakarta : Djambatan, pg.34

Benhard Limbong. (2011). Pengadaan Tanah Untuk Pembangunan: Regulasi, Kompensasi Penegakan Hukum. Jakarta : Pustaka Margareta, pg. 129
}

Land acquisition for public purposes cannot be separated from the concept of public interest. Roscoe Pound, giving a definition of interest as wishes or demands, the man tried to comply, either individually or in groups, or in the set which must be considered by the governing relationships between humans or regulate human behavior. ${ }^{3}$

Relating to the interpretation of public interest, at first very broad interpretation of the public interest which is using the standard "public necessity", "public good" and "public utility". But in its development in the $19^{\text {th }}$ century, the comprehensive standard began to be abandoned and began to be treated the basic principles narrow. The basic principle of public interest in the United States is if a property is taken for public use, it must "be used by the public". In fact, it is only "useful to the public" is still not used to the public then the requirement of public interest is considered not met. ${ }^{4}$

Maria SW Sumardjono ${ }^{5}$ proposed that the concept of public interest in addition must meet the "allotment" also must be perceived usefulness (for public use). According to Michael G. Kitay, ${ }^{6}$ said there are 2 (two) ways to determine the public interest: the first general guidelines; providing a

\footnotetext{
Paton George Whitecross as cited in Ade Maman Suherman. (2004). Pengantar Perbandingan Sistem Hukum. Jakarta : PT. RajaGrafindo Persada, pg. 46

Ibid.

Maria S.W Sumardjono,. (1990). Telaah Konseptutual terhadap Beberapa Aspek Hak Milik, Sebuah Catatan untuk Makalah Chadijdjah Dalimunte, Konsep Akademis Hak Milik Atas Tanah Menurut UUPA, Paperwork on Seminar Nasional Hukum Agraria III Fakultas Hukum Universitas Sumatera Utara-Badan Pertanahan Nasional, Medan 19-20 September 1990. Page. 13

6 Michael G Kitay. (1985). Land Acquisition in Developing Countries', Policies and procedures of public sector, with survey and case studies from Korea, India, Thailand, and Equador, Oelgeschlager. Boston : Gunn \& Hain Publishers Inc. pages. 39-41
} 
general provision against the public interest such as social interest, public interest, collective interest or shared. The general guidelines are given by the legislature, and in its implementation, the executive that determines what kind of public interest. Second, list provisions; the determination of public interest. Kitay stated further that most countries now combine both methods in the regulation of land acquisition. In addition to making a general statement, the public interest has also been relegated to the list of activities in a limited manner.

John Salindeho has formulated public interest as the interests of nation and country as well as the collective interests of the people, taking into account aspects of social, political, psychological and national defense and security upon the principles of national development with regard to National Security as well as Archipelago. ${ }^{7}$ Oloan Sitorus also added that in addition to the allotment and its use it must be determined party can carry out development in the public interest and the nature of the public interest, it still provides the possibility for manipulation to the public interest.

As described above that the public interest is the interest relating to the benefits to the public either directly or indirectly that does not distinguish the background of society so that the public interest is included in the term known as the "dominate the life of many people."

\section{Philosophical Aspect of Land Acquisition}

The underlying philosophy must be the basis of the implementation of land acquisition is

John Salindeho. (1988), Masalah Tanah Dalam Pembangunan. Jakarta : Sinar Grafika. page. 40 similar as the underlying philosophy of land registration process set out in UUPA that is Pancasila in this case the second, fourth and fifth principles.

Pancasila as the philosophy of land acquisition can be found in the preamble letters (a) and (b) of Act No. 2 of 2012 concerning Land Acquisition for Development for the Public Interest letters a and b. Inclusion of the underlying philosophy must ensure that development activities have clarity regarding the allocation of interest, how to carry out acquisition and steps to achieve intended manner.

Essentially, any legislation enacted in Indonesia is an elaboration of the values contained on the principles of Pancasila as the philosophy of life of the Indonesian nation. Land acquisition set out in the legislation related to the land acquisition in Act No. 2 of 2012 on the part of preamble contained political legislation in the first few points, that in order to realize a society that is just, wealth and prosperous based on Pancasila and the Constitution of the Republic of Indonesia 1945, the government needs to implement development; second, that in order to ensure the implementation of development for public interest, the land is necessary that its acquisition carried out by promoting humanitarian principles, democratic and fair; third, that the legislation in the field of land acquisition for the development of public interest cannot guarantee the land acquisition for the implementation of development; fourth, that based on the considerations as mentioned in letters $\mathrm{a}, \mathrm{b}$, and $\mathrm{c}$, it is necessary to enact the legislation on Land Acquisition for the Development of Public Interest. 
The description above indicates that philosophically the land acquisition of public interest is an activity of land acquisition for the implementation of development for public interest guided by the principles of Pancasila embracing the principles of humanitarian, democratic and justice.

\section{Sociological Aspect of Land Acquisition}

Land acquisition in Ujang Bahars' view was re-quoted by Sujarwo Marsoem et.al ${ }^{8}$ had two double functions which function as social assets and as capital assets. Social assets means that the land is a social binder means to live while the land as a capital asset means that the land is a capital factor in the economic development of owner.

Discussion of the principles of general interest in the land acquisition for development is closely related to the means of development, especially the development in the field of material requiring the land as the primary means. Land acquisition for development for public interest is between the two conditions namely the ownership of land by individuals as described in Article 9 paragraph (2) UUPA on the one hand and development interests on the other hand so that the ownership of land by individual at any time can be disqualified due to the development for public interest.

The difference in interest is seen also from the conditions in which society requires development while individual requires land as a place of settlement and livelihood. Land acquisition is carried out to find a meeting

\footnotetext{
Sodjarwo Marsoem et al. (2015). Pedoman Lengkap Ganti Untung Pengadaan Tanah, Memetakan Solusi Strategis Pengembangan Infrastruktur di Indonesia. Jakarta : Renebook. page. 59
}

point between the two interests in a development that does not usurp the rights of individuals.

In this case, land acquisition for development of public interest is carried out carefully and with a wise way. Land acquisition is the first step to do when the government requires a plot of land for public interest or for the benefit of which can support development. In addition, land acquisition for development of public interest remains to be adapted to local communities and not impartially for the benefit of certain groups.

Thus, if there is a development project in the society, then in accordance with the principle of public interest, then the land rights of community not become the object of public interest. Land use must be adapted to the circumstances and the nature of their rights, to benefit the welfare and happiness or also benefit for society and state.

The description above shows that sociologically, land acquisition to accommodate respect for human rights, namely the well-being and a decent life for its owners.

\section{Juridical Aspect of Land Acquisition}

The arrangement of tenure and land ownership in Indonesia after 1960 conducted by UUPA amendment Agrarische Wet (Staatsblad 1870 No. 55) and all their derivatives in which UUPA gives the provision of the land rights while providing restrictions on land rights with the function of land social where every individually land ownership should consider the rights of public and the public interest.

Follow-up of the land social function is carried out by issuing of Act No. 20 of 
1961 concerns Revocation of land Rights and Objects in it that allows the state to revoke the rights of citizens on the land by giving compensation if the state needs it for development activities.

The interest of development in the early of new order requires facilities and infrastructure in large numbers, so that the land acquisition by the government for development purposes is increasingly in need of a mechanism to prevent and resolve conflicts that may arise in the process of land acquisition. In particular, conflicts that arises due to the differences in the interests between the government and landowners.

Given the importance of provision mechanisms for land acquisition due to the demands of development is more incentive then issued Presidential Instruction No. 9 of 1973. Furthermore, in 1975, after the issuance of Presidential Instruction No. 9 of 1973, issued the Regulation of Domestic Minister No. 15 of 1975 as the implementation rule of Act No. 20 of 1961. The regulation of Domestic Minister No. 15 of 1975 regulates the land acquisition for government interest and acquisition for private interest.

For more than twenty years in the regulation of Domestic Minister No. 15 of 1975 enacted but its implementation still find a lot of problems so that in 1993 issued Presidential Decree No. 55 of 1993 as a replacement for Domestic Minister No. 15 of 1975. Presidential Decree No. 55 of 1993 contains law substance concerning the procedure of land acquisition in two ways: firstly, releasing of land rights for land acquisition for public interest, and secondly, buying and selling, exchange, and other means that are based on agreement between the landowner and parties who requires land for land acquisition for the interest and not public interest.

Presidential Decree No. 55 of 1993 further amendment by Presidential Regulation No. 36 of 2005 as governments' efforts to resolve conflicts in land acquisition during the implementation of Presidential Decree No. 55 of 1993 which is considered more pro-employer groups. One year of enactment of Presidential Regulation No. 36 of 2005 conducted amendment by issuing Presidential Decree No. 65 of 2006. Significant changes in Presidential Regulation No. 65 of 2006 is arrangements concerns custody to the court or consignment as a test of legality to verify the qualifications of public interest in a development project and do test against land acquisition procedures are implemented.

Besides the issue of consignment, another interesting thing in Presidential Regulation No. 65 of 2006 was the use of taxable value (NJOP) as a benchmark or basis for compensation, but in fact the implementation lead to conflict because society assess their land based on market prices.

Efforts to improve regulation regarding land acquisition is one of political will of state officials to put the individual and public interests as two sides are in line, not the opposite, conflicting, opposite and facing. The existence of Act No. 2 of 2012 then followed up with the enact of Presidential Regulation No. 71 of 2012, No. 40 of 2014, No. 99 of 2014 and No. 30 of 2015, the Regulation of National Land Agency No. 5 of 2012 concerns Technical Guidance on 
Land Acquisition, as well as the Regulation of Agrarian and Spatial Planning Minister/ Head of National Land Agency No. 6 of 2015 on the Amendment of Technical Guidelines of Land acquisition on Amendments to the Regulation of National Land Agency No. 5 of 2012 concerns Technical Guidelines for the Implementation of Land Acquisition.

Respect for the individuals' rights is an obligation of the state to the citizen. This is an important issue in the history of land acquisition in Indonesia since the enactment of the Domestic Minister No.15 of 1975 concerns Land Acquisition Rights. Weaknesses in the regulation then attempted to be fixed by issuing subsequent regulations. Efforts to establish the law in order to create legal certainty for government and society is a consequence of the ideal of a law state adopted by Indonesia. Therefore, legally it can be said that the land acquisition is one of efforts to realize the law state through the creation of legal certainty for the government as a party to obtain land for the sake of the implementation of its functions and legal certainty for landowners as a party that has rights that must be protected under any circumstances.

The Problematic of Small-Scale Land Acquisition (Less Than 5 Hectares)

Small-scale land acquisition in the legislation of land acquisition is set initially in Article 121 of Presidential Regulation No. 71 of 2012 which confirms that in the context of efficiency and effectiveness, land acquisition for public interest that its area less than 1 (one) hectare can be done directly by the agency requiring the land to all holders of land through buying and selling, exchange or other means as agreed by both parties. The provisions of Article 121 is amended in Presidential Decree No. 40 of 2014 on Amendment of Presidential Regulation No. 71 of 2012 on the Implementation of Land Acquisition for Public Interest Development which confirms that in the context of efficiency and effectiveness, land acquisition for public interest that its area less than 1 (one) hectare can be done directly by the agency requiring the land to all holders of land through buying and selling, exchange or other means as agreed by both parties. In the Minister of Agrarian/Head of National Land Agency No. 6 of 2015 further stipulated that the small-scale land acquisition with an area of 5 hectares using appraisal to determine the price of land.

Small-scale land acquisition that is 5 (five) hectares have been set up in several Presidential Regulation and the Regulation of Agrarian and Spatial Planning Minister as described above, but against this arrangement author examine issues that require study and further research related to problems that may arise due to such arrangements.

\section{Planning and Preparation}

Presidential Regulation No. 40 of 2014 in vague provides arrangement that land acquisition less than 5 hectares is done by direct purchase. It is described in a very short and simple. There are no further arrangements regarding the direct purchasing mechanisms referred to in the regulation. Presidential Regulation No. 40 of 2014 only explained that the land acquisition can be done through buying and selling or exchange 
or other means agreed by both parties. The arrangement in this regulation in the view of the authors did not explain about requirements for determining location of small-scale land acquisition. The requirement of location is stipulated in the Regulation of Agrarian and Spatial Planning Minister/Head of National Land Agency No. 6 of 2015 which is in accordance with the spatial in the area. In view of author, this arrangement has not been able to answer problems that may arise in the implementation of small-scale land acquisition.

In a large-scale land acquisition mechanism (over 5 hectares) determining the location of acquisition followed up with notice of the development plan, the initial data collection, and public consultation. This mechanism is a very important mechanism for determining the appropriateness between development with the public interest as well as a spot for governments to obtain the consent and understanding of the public so it will not cause rejection or other action that may hinder future development in the implementation process.

Land area of 5 hectares, in reality, can be used for physical development and activities that have a big impact for the people and 5 hectares is still possible is shared by many people who are prone to conflict so that arrangements for smallscale land acquisition that does not regulate the planning mechanism will be decided between the development goals with public participation. The mechanism of planning and preparation is a very important step because it would support public understanding and acceptance for development.

\section{Pricing}

The pricing of land to be purchased by agencies require land has set in the Agrarian and Spatial Planning Minister/Head of National Land Agency No. 6 of 2015 that is using appraisal team. It is of course to avoid speculation or practices that are detrimental to the country as many occur in a period before the establishment of the Land Acquisition Act. None of the substantive law relating to the small-scale land acquisition regulates appraisal selection mechanism. It is different from the large-scale land acquisition has insisted that the determination of appraisal carried out through an auction mechanism. In fact, without arrangement for appraisal determination mechanism for small-scale land acquisition raises doubts for those who need land to carry out small-scale land acquisition.

The further problem related to the price of land is no mechanism that regulates the efforts made by the agency requiring the land if landowners do not agree to land acquisition carried out or do not agree with a set price appraisal. This is in contrast to the large-scale land acquisition clearly regulating the period for filing objections and attempts consignment over the objections or issues that arise in land acquisition.

\section{Ideal Concept of Small-Scale Land Acquisition}

Legislation as a legal product intended to comply by the public or in other words, to be effective, the legal act in accordance its function. To realize the function of legislation, then there are 3 (three) criterion must be met: First, if the act only applies 
legally it is most likely that the rule is only a rule die (dode regal); Second, if the act applies only sociologically it may apply the law as simply as a rule enforcer; Third, if the act only applies philosophically then maybe the law will only become law aspired. ${ }^{9}$ Legislation is one of the powerful methods and instruments available to regulate and direct the lives of people toward the ideals expected and related to the purpose of legislation. A. Hamid Attamimi suggested that things are done by the legislators are giving directions and show the way for the realization of the ideals of the nation through the establishment of law. ${ }^{10}$

Norms or rules are institutionalizing the values of good and evil in the form of rules that contain permissibility, suggestions, or command. Suggestion or commands can contain rules that are positive or negative so than includes suggestion to do or not to do, and command norms to do or not to do. In terms of etymology, the word norm itself comes from the Latin, while rules come from Arabic. Norm comes from the word nomos which means the value and then narrowed it means to be a legal norm. Platos' work titled Nomoi usually translated into English by The Law. While the rules in Arabic, qo'idah means the size or gauge value. ${ }^{11}$

In terms of its objectives, Bryan Garner in Asshiddiqie ${ }^{12}$ argued that legal rule or legal norm was drawn to the ideal of peaceful inter-

$9 \quad$ Soerjono Soekanto. (1979). Kegunaan Sosiologi Hukum Bagi Kalangan Hukum. Bandung : Alumni. page. 121

10 A. Hamid Attamimi. (1992). Teori Perundang-undangan Indonesia, in Inauguration Speech Professor of Law at Faculty of Law University of Indonesia, Jakarta, Apr 25, 1992, pg. 8

11 Jimly Asshiddiqie. (2006). Perihal Undang-Undang. Jakarta : Konstitusi Press, pg. 4

$12 \quad$ Ibid.pg. 6 personal (het recht wil de vrede). Therefore, it is often said that the law enforcement work "to preserve peace". In peace or peaceful state there is always the "orde en rust". "Orde" concerns order and security, while the "rust" concerns to peace and tranquility. Orde related to outer dimensions, while rust related to inner dimensions. Peaceful state is the ultimate goal of legal norms lies in the balance between the rust and orde is the outward and inward dimension that produces a balance between order and safety, security and tranquility.

The goal of living peace together is usually associated also with the task of formulating legal rule, which is to achieve certainty, equity, and usefulness. That is, every legal it must produce a balance between the value of certainty (zekerheid), equity (billijkheid, evenredigheid), and utility. There is also a scholar who only mentions the importance of duumvirate of legal rule, legal certainty (rechtszekerheid) and legal equity (rechtsbillijkheid). ${ }^{13}$

The regulation of land acquisition as part of efforts to realize a land acquisition process that guarantees a legal certainty, equity and provide benefits to the people so that the substance of law adopted should be in the corridor achieving the three objectives of law. Obscurity or vagueness of arrangements regarding setting one object will cause a problem of vagueness, multiinterpretation in defining and understanding the legislation will even become an obstacle to the achievement of the purposes of law. Land acquisition for public interest is a manifestation of the social function of land

$13 \quad$ Ibid.pg. 7 
rights. Land acquisition is an important part of a process to achieve equitable development, welfare and prosperity of the people so that the land acquisition is basically to people. However, taken the land belongs to the people still have to pay attention to the rights of the people by providing compensation for land taken for the public interest.

Article 1 point 10 of Act No.2 of 2012 has been formulated decent and fair compensation to the parties entitled to the land acquisition process. This indicates that the compensation in land acquisition is a form of appreciation and respect for individual rights are being sacrificed to the public interest. The balance between individual and public interests in the provision of land was an equity for both, because the government as a party in need of land to acquire land to be used for the implementation of its functions relating to the lives of many people, whereas individuals obtain redress for the land. In addition, the authors argued also that the transfer of rights on the land, accompanied by compensation for the land owned by the people is a form of peoples' participation in development, so that the nature of land acquisition, which is still less discussed and used as discourse is essentially as public participation in development.

The linkage between land acquisition and the public interests are like two sides of a coin that cannot be separated so that the entire land acquisition process should be based on a balance between the two. Efforts to balance all the interests relating to the land acquisition which is then based every stage of the land acquisition process set out in the legislation for land acquisition. But in reality, the arrangement comprehensively and balanced is only aimed at the large-scale land acquisition while small-scale has not shown the existence of arrangements leading to the achievement of a balance between the interests of development with the public interest and are still far from achieving the objectives of law, namely certainty, equity and benefits with the advent of the problems as previously described.

On this basis, the authors examine several point solution that can address these problems:

First, the small-scale land acquisition detail of planning document above shows that the nature of planning and preparation in the stages of land acquisition by local governments is a phase of synchronization between the development needs with location where the land acquisition will be implemented, including social, economic, psychological and cultural conditions (less than 5 hectare) as well not losing the essence of the land acquisition as part of government efforts to implement development that balances the interests of development and public interests so that both large and small, the planning stage is a part that cannot be eliminated. This plan included an analysis of costs, benefits and impacts that would arise from the land acquisition so that the ability of local governments in the preparation of planning documents should really be based on a research and in-depth analysis of the needs of development and the impact that will be received as a result of land acquisition and development plan. Smallscale land acquisition in the author's view requires synchronization between the stages 
of planning and implementation for this plan will be the basis for the next stages. Without planning, the process of implementation and its goal will experience a gap that led to the state losses and damages society.

Second, public consultation and socialization is a very important stage and shall be implemented in accordance with the provisions of Act No. 2 Year of 2012 and Presidential Regulation concerning land acquisition. Socialization is the stage at which the land acquisition plan submitted to the public and is expected with this socialization will obtain feedback and input from the public pertaining to land acquisition will be implemented. Socialization is also a decisive stage of public participation or public participation in the planning stages of land acquisition so that it becomes a very important stage for the emergence of objection and other issues later.

Socialization in this case will give an enlightenment and explanation to the public so that people can really understand the goals, objectives and the things they would face with regard to their land acquisition activities. Therefore, socialization can also be called as an attempt mapping problems that local governments really know the probable obstacles to be faced in the process of land acquisition. Really, socialization needs to be able to convey all matters relating to the land acquisition. Ideally, socialization was attended by all members of society, both parties are entitled and which will receive the impact of land acquisition so that someday in the future will not give rise to a conflict that would hinder the implementation process of development. This is a very big responsibility for local government in this case the governor or regent/mayor. Socialization is essentially a process to popularize a plan and to be accepted and understood by the public as well followed the socialization of the system need to accommodate cultural or social system growing sector in the community. The arrangement of public consultation and socialization is appear only intended for large-scale land acquisition, as can be discerned from the provisions of the Regulation of the Agrarian and Spatial Planning Minister/Head of National Land Agency No. 6 of 2015 which do not require the application of the provisions of the Land Acquisition Act No. 2 of 2012 in its implementation.

Third, determining the location of which will be the object of land acquisition is considered accordance with the purposes of development so that if a location has been specified then if all objections to the location already settled well accepted and it was decided to move it, then there is no effort for the community longer associated with that location and if they refuse then they are welcome to take legal action. It is only for large-scale land acquisition. For small-scale land acquisition, there is no mechanism that regulates both public rejection solutions for the location and the price of land. The basis of land acquisition for small-scale is only deal with the landowner. This suggests that if landowners do not agree then no other efforts that can be done other than to move the location.

Fourth, the regulation concerning the obligation to use the appraisal for smallscale land acquisition is not accompanied 
clarity for appraisal selection mechanism whether auction or direct appointment so that arise doubt for agencies that need the land for public interest.

Observing the description above the author considers that the arrangement of small-scale land acquisition requires a more comprehensive legal substance and should not be set vague as it is today. The various problems that might arise should be anticipated with a legal substance that contains some of the things that the author deserves to be accommodated the arrangements regarding the planning, preparatory phase especially public consultation and socialization, dispute resolution mechanism and appraisal determination mechanism.

\section{CONCLUSION}

The problematic of small-scale land acquisition in the legal substance of land acquisition in the legislation, Presidential Regulation and the Regulation of the Agrarian and Spatial Planning Minister/Head of National Land Agency were still very vague and not comprehensive because it includes the stages of planning and preparation, not arrange appraisal determination mechanism, mechanism to resolve objection or dispute in the land acquisition which can lead to uncertainty, inequity and reduced the benefits of land acquisition for the entire party. Solutions that can be taken is doing legal substance arrangement concern smallscale land acquisition which includes the stages of planning and preparation by local authorities, arranging mechanisms for determining appraisal and to resolve problems or disputes in land acquisition.

\section{BIBLIOGRAPHY}

A. Hamid Attamimi. (1992). Teori Perundang-undangan Indonesia, in Inauguration Speech Professor of Law at Faculty of Law University of Indonesia, Jakarta, Apr 25, 1992.

Ade Maman Suherman. (2004). Pengantar Perbandingan Sistem Hukum. Jakarta : PT. RajaGrafindo Persada.

Benhard Limbong. (2011). Pengadaan Tanah Untuk Pembangunan: Regulasi, Kompensasi Penegakan Hukum. Jakarta : Pustaka Margareta.

Boedi Harsono. (1991). Hukum Agraria Indonesia Himpunan Peraturan-Peraturan Hukum Tanah. $10^{\text {th }}$ editions. Jakarta : Djambatan.

Jimly Asshiddiqie. (2006). Perihal UndangUndang. Jakarta: Konstitusi Press.

John Salindeho. (1988), Masalah Tanah Dalam Pembangunan. Jakarta : Sinar Grafika.

Maria S.W Sumardjono,. (1990) . Telaah Konseptutual terhadap Beberapa Aspek Hak Milik, Sebuah Catatan untuk Makalah Chadijdjah Dalimunte, Konsep Akademis Hak Milik Atas Tanah Menurut UUPA. Paperwork on Seminar Nasional Hukum Agraria III Fakultas Hukum Universitas Sumatera Utara-Badan Pertanahan Nasional, Medan 19-20 September 1990.

Michael G Kitay. (1985). Land Acquisition in Developing Countries', Policies and procedures of public sector, with survey and case studies from Korea, India, Thailand, and Equador, Oelgeschlager. Boston: Gunn \& Hain Publishers Inc. 
Presidential Regulation No. 30 of 2015 concerning the Fourth Amendment of Presidential Regulation No. 71 of 2012 concerning the Implementation of Land Acquisition for Development of Public Interest.

Presidential Regulation No. 40 of 2014 concerning the Second Amendment to Presidential Regulation No. 71 of 2012 concerning the Implementation of Land Acquisition for Development of Public Interest.

Presidential Regulation No. 71 of 2012 concerns the Implementation of Land Acquisition for Development of Public Interest.
Presidential Regulation No. 99 of 2014 concerning the Third Amendment to Presidential Regulation No. 71 of 2012 concerning the Implementation of Land Acquisition for Development of Public Interest.

Regulation of Head of National Land Agency No. 5 of 2012 concerning Technical Guidelines for Land Acquisition.

Sodjarwo Marsoem et al. (2015). Pedoman Lengkap Ganti Untung Pengadaan Tanah, Memetakan Solusi Strategis Pengembangan Infrastruktur di Indonesia. Jakarta: Renebook.

Soerjono Soekanto. (1979). Kegunaan Sosiologi Hukum Bagi Kalangan Hukum. Bandung: Alumni. 